\title{
EFFECTS OF PROBIOTICS (Bacillus sp.) ON GROWTH PERFORMANCE OF JUVENILE ORANGE SPOTTED GROUPER (Epinephelus coioides)
}

\author{
MOHD YUSRHAFIZMAN MOHD AZMI, MOHAMAD HAFIZZUDDIN MOHAMED AND \\ SHARIFAH NOOR EMILIA*
}

Faculty of Fisheries and Food Science, Universiti Malaysia Terengganu, 21030 Kuala Nerus, Terengganu, Malaysia.

*Corresponding author: emilia@umt.edu.my

http://doi.org/10.46754/umtjur.2021.07.007

\begin{abstract}
The present study conducted was to investigate the effect of probiotics (Bacillus sp.) on the growth performance of juvenile orange spotted grouper (Epinephelus coioides). Probiotic (Bacillus sp.) of different concentration; $10^{6}(\mathrm{~T} 1)$ and $10^{7}(\mathrm{~T} 2) \mathrm{CFU} / \mathrm{ml}$ was sprayed on the feed, while a control (C) group was fed no probiotics. A total of 60 juvenile orange spotted grouper were used in this experiment. Each treatment had 3 replicates and each replicate contained 10 juveniles. The experiment was conducted for 31 days. The feed was given by calculation $3 \%$ of body weight of the grouper each week and the fish were fed 3 times a day. As for the result, neither T1 nor T2 treatments showed any significant improvement in the growth performance of the grouper when compared the control group. In T1, there is a significant difference in Feed Conversion Ratio (FCR) only when compared with the control group. In this study, control showed better growth performance result may be caused by the insufficient concentration of probiotics in diets of juvenile Epinephelus coioides. Lastly, no mortality rate was recorded in this study. Overall, the inclusion of $10^{6}$ and $10^{7}$ $\mathrm{CFU} / \mathrm{ml}$ of probiotic (Bacillus sp.) did not give desirable results towards growth performance of juvenile Epinephelus coioides and should be retested with a higher dosage.
\end{abstract}

Keywords: Probiotic, Bacillus sp., Epinephelus coioides, growth performance, comparison

\section{Introduction}

\section{Background of study}

Aquaculture can become a sustainable practice that supplies fishing and contributes significantly to feeding the world's growing population. However, rather than helping to alleviate the wild fisheries crisis, unsustainable development of aquaculture could aggravate the issues and generate fresh ones, damaging our important and already stressed coastal regions. With most catch fisheries deemed to be fully exploited or overexploited globally, aquaculture will be essential to meet the demand for fish, which will continue to increase with population growth, higher incomes and increased urbanization. However, as aquaculture grows, governments will need to handle their future effects on the environment and on society. The bulk of global aquaculture is in Asia. In 2002, China alone accounted for over $70 \%$ of global aquaculture production.
The global fish production peaked at around 171 million tons in 2016, according to Ababouch et al. (2016), with aquaculture accounting for 47 percent of the total and 53 percent without nonfood uses, including reductions in fish meal and fish oil. Since the early 1980's, aquaculture has been responsible for the continuing remarkable growth of fish supplies for human consumption with fairly stagnant fish capture production. According to Abalobi (2017), the average annual rise in worldwide consumption of food fish between 1961 and 2016 was 1.6 percent above population growth and 2.8 percent above that of meat from all terrestrial animals combined.

Aquaculture cultivates aquatic organisms such as fish, molluscs, crustaceans and also aquatic plants like seaweed which are capable of supporting worldwide food production, increasing job opportunities and accelerating the global economy by generating profit (Tidwel 
et al., 2018). Farming of aquatic organisms, including fish, molluscs, crustaceans and aquatic plants, according to FAO (2010). Farming involves other processes, not just breeding such as periodic storage, feeding or predator protection. Public-listed companies can also be involved in farming inventory that is either privately-owned or in a cooperative. It is also reported that aquaculture in the last decades has grown rapidly as a counterpart to agriculture and is now generating as much fish and seafood as fish capture(FAO, 2014). The primary means of obtaining more food in the future is through aquaculture for our aquatic environments. Large quantities of fish are currently harvested to generate fish meal and fish oil (FAO, 2014), an important source of protein and fatty acid in food for many species of fish and shrimp. The quantity of non-food use is steadily declining. But the demand from the aquaculture sector is still high and can lead to unsustainable fishing methods with potential adverse effects on fish stocks and the marine food web (Cao et al,. 2015). The worldwide use of fish meal and fish oil by aquaculture industry increased threefold between 1992 and 2006 (Hasan \& Halwart, 2009). The result of the development in the feed sector was a reduction in feed conversion ratios and appropriate fish resource production. Aquaculture has dramatically increased in global production since the early 1950s, according to Phillips et al (2016). The growth of the population that began in the 1950s is in line with that. (Bongaarts, 2009).

Aquaculture began in Malaysia in the twenties with the completed multicultural development of introduced Chinese carps in disused mining ponds, mainly big carp, silver carp and grass carp. In the late 1930s in Johore, South Malaysian Peninsular, marine shrimp trapping ponds were established. Blood cockles (Anadara granosa) were cultivated in the beginning of the 1940s. In the mid-1950s, this was followed by an extensive breeding of freshwater fish in earthen ponds. At the beginning of the 1970s, when a semi-intensive shrimp culture was established in Johore, excellent changes in aquaculture began to take place. The floating net cage cultivation of marine fish, primarily the green grouper (Epinephelus coioides), began to take place during the same era, followed by the raft cultivation of Green mussel (Perna viridis). Marine finfish (Epinephelus sp) and marine bass (Lates calcarifer) are bred and cultivated (Hanafi, 2013). Aquaculture in brackish water is the predominant practice, but there is also aquaculture in freshwater ponds and in marine environment. According to Pierre et al (2008), grouper fish culture has significant economic value in the tropical world.

The grouper is commonly found in tropical and subtropical waters There are about 110 species of groupers in the Indo-Pacific areas (Heemstra, 1991;Kohno et al., 1990; Randall, 1987) and about 159 species around the world (Heemstra \& Randall, 1993). $90 \%$ of world marine food production is projected to be derived from traditional fishing and clumps form an important part of handicraft fishing (Heemstra \& Randall, 1993). Local and global markets, particularly in Southeast Asia (Hong Kong, Singapore) and in Japan (Kuo, 1995), search for these fish. Groupers are cultivated in many nations in Southeast Asia such as Indonesia, Malaysia, the Philippines, Taiwan, Thailand, Hong Kong, Southeast China and Vietnam, and in the Southeast (Tucker, 1999) and the Caribbean tropical areas. In Southeast Asian fish farms, seventeen grouper species are grown, the dominant species varying based on the nation of origin (Sadovy, 2001). However, the wild-caught species most frequently found destined for aquaculture, or those grown in hatcheries are E. coioides, E. malabaricus, E. bleekeri, E. akaara, E. awoara, E. areolatus, E. amblycephalus, E. fuscoguttatus, E. lanceolatus, E. sexfasciatus, E. trimaculatus, E. quoyanus, E. bruneus, Cromileptesaltivelis, Plectropomusleopardusand $P$. maculatus. Malaysia's most popular grouper fish cultivated are E. coioides, E. malabaricus, E. tauvina, E. fuscoguttatusand E. Lanceolatus situated in the Malaysian Peninsula in the coastal protected areas of Johor, Perak, Penang and Kedah (Pomeoyet al. 2002). 
The sustainable development of the grouper sector was endangered by the degradation of germplasm resources and the accessibility in hatcheries of grouper fries. Hybridization technology was launched into grouper artificial reproduction to solve these issues. (Kiriyakit et al.,. 2011). Because of its multiple favourable characteristics, such as quicker growth and development, greater immunity and greater survival rates, the hybrid grouper became extremely popular among farmers. (James et al. 1999; Glamuzina et al. 1999; Glamuzina et al. 2001; Liufu, et al. 2007; Yan Wang, et al. 2014). However, this invasive species will lead to the loss of keystone species, the loss of pollinators and modified natural invasions, as well as drivers of ecosystem degradation, such as habitat change and exploitation, environmental pollution, climate change and related impacts (Millenn. Ecosyst. Assess. 2005 ; Pysek et al. 2006 ; McGeoch et al., 2010).

The orange spotted grouper (Epinephelus coioides) is one of the major fishing commodities in Asian countries. Seafood is extremely common in Malaysia, Indonesia and Hong Kong and is intensively and widely grown (Tenget et al 1978: Liu \& Mitcheson 2008: Sugama et al 2008). Extensive semi-intensive aquaculture, particularly in the province of Aceh, is popular in Indonesia and basil fish is generally used as feed for fish.. Due to its outstanding taste and scarcity value, Orange spotted grouper is a popular marine food fish with elevated market value in Southeast Asia. In the Western Pacific and Indian Oceans, it is commonly spread. The species is a popular target fish for fishermen in Indonesian waters and is deemed a desirable crop fish (Kohno et al., 1991). In Taiwan, Thailand, Malaysia, Singapore and China, it was commercially farmed in marine cages and lakes (Rimmer. 1998). Due to the unusual supply of seed, the orange spotted grouper culture was globally popular. The species is naturally accessible in Malaysia and is cultivated in Sabah and Island of Langkawi. Nowadays, however, Farmers have lost interest in the orange spotted grouper, and they are now not as extensively cultivated because of the slow development results (Mazlan, et al. 2016) and have started to cultivate another hybrid grouper. To solve this issue, therefore, is to introduce probiotic use in daily food on grouper fish to improve growth efficiency.

Probiotics are a live microbial feed supplement, according to Fuller (1989), which benefits the host animal by enhancing its intestinal balance. Fuller also suggested that the word "probiotic" would inevitably refer to gram-positive bacteria associated with the Lactobacillus gene, but some factors are required in aquaculture. Probiotics may increase the concentration of beneficial microorganisms, microbial enzyme activity by improving the intestinal microbial balance and improving the digestibility and absorption of food and feed use (Bomba et al., 2002).

\section{Problem Statement}

The main problem in culturing Orange spotted grouper is the slow growth performance (Mazlan, et al,. 2016) and this causes that the farmers to lose interest in farming orange spotted grouper. However, according to Forsskal (1775), one of the most sought-after fishing commodities in Asian nations was the orange spotted grouper. This is mainly due to the fact that the grouping culture is most established in the Asian nation, particularly in the Hong Kong, Singapore and Taiwan industries, due to the high commercial importance of these fish. Orange spotted grouper widely cultivated in Malaysia , Indonesia and Hong Kong (Teng et al 1978; Liu \& Mitcheson 2008; Sugama et al 2008). The orange spotted grouper has been commonly cultivated throughout Malaysia in the pond and cage culture. The existence of grouper species hybridization with more important benefits such as development and manufacturing effectiveness, nutritional requires quality and environmental resilience (Abdullah et al. 2018), demand for natural grouper culture is steadily decreasing.

Also known as invasive species are the hybrid species. According to (Pysek et al., 
2000; 2004), invasive species are alien species that maintain a life-cycle of self-replacement, generate reproductive offspings often in very large numbers at significant distances from the parent and/or the place of entry, and have the ability to spread over long distances. However, these hybridization clusters also pose a significant risk to the ecological setting that affects ecosystem degradation, such as changes in exploitation and habitat, environmental pollution, climate change, loss of keystone species, pollinator loss and the modified functioning of the ecosystem (Pysek \& Richardson, 2010) if these hybrid species escape to the wildlife. However, because it is natural species, growing orange spotted grouper will not endanger the natural environment. Native species means species that develop over time without human interference in a certain region or that came naturally without human factors in a specific region. (Pysek, et al., 2004). Research is therefore now intensifying on the use of probiotics for aquaculture to help boost fish growth (Priyadarshini Pandiyana et al. 2013).

\section{Significant Study}

The ultimate goals in carrying this study is to determine the positive effect of introducing the probiotics to the diets which enable you increase the growth rate performance of Epinephelus coioides. In this experiment, Bacillus sp. was used as growth promoter in diets of Epinephelus coioides. The objective is to determine the effects of this probiotic on the improvement of the growth rate of the orange spotted grouper. If the growth rate can be improved by using this probiotic, it can overcome the slow growth rate of orange spotted grouper, increase annual fish yield, and increase farmers' income.

\section{Study Objective}

The main objective of this research is to study the effects of the probiotic Bacillus sp. in $10^{6}$ and $10^{7}$ concentration on the growth rate performance of Epinephelus coioides juvenile (Orange spotted grouper).

\section{Materials and Methods}

\section{Study site}

This experiment was conducted using six 900-litre tanks for 31 days at Marine Water Hatchery station of the Faculty of Fisheries and Food Sciences, Universiti Malaysia Terengganu, Malaysia. The fiber tank were filled with 100 litres marine water in 15-20 ppt (Noorashikin et al, . 2018). The fish juveniles were put in treatment tank once they arrived at study site for adaption purpose after shipping process before divided into rearing tank.

\section{Juvenile source}

60 juvenile-Epinephelus coioides of both sexes were used in this experiment. The fish were obtained from a farmer at Teluk Senangin, Perak.

\section{Preparation of probiotic and feed}

Probiotic Bacillus sp. was obtained from the UMT Marine Biotechnology Institute (IMB). The duration of probiotic used may be assessed as short as 6 days (Joborn et al., 1997) and more than 5 months (Aubin et al., 2005) or even 8 months (Aly et al., 2008). Bacillus sp. was cultivated on marine agar at an appropriated temperature of $30-37^{\circ} \mathrm{C}$ with a minimum temperature of $18{ }^{\circ} \mathrm{C}$ and a maximum temperature of $43{ }^{\circ} \mathrm{C}$ from 24 hours onwards (Cook \& Korsten, 1996). According to Satomi et al (2006), the formation of colonised of Bacillus sp. were round, dull white, undulated, nonluminescent and have irregular margins.

\section{Experimental design}

One nursing tank was used to treat the fish upon arrival. The filtered water was filled in the tank one week before the stocking of the fish. All the fibre tanks were prepared and then juveniles were released into the tank which were filled with aerated seawater. The mesh size of 1.0-5.0 $\mathrm{mm}$ was used and changed regularly to remove the dirt, waste food and fish faeces. Six fibre tanks of 100 litres each were used in 
these experiments. The tanks were divided into 2 groups Treatment and Control tanks. The tanks that were labelled as 'Treatment' were given basal diet with probiotic Bacillus sp. while for the tanks that labelled as 'Control' were given basal diet without probiotic Bacillus sp. There were two treatments with three replicated of each using one concentration of probiotic Bacillus sp. which are $10^{6}$ and $10^{7}$ Colony Forming Unit (CFU) per day. There were also one types of controlled tank with three replicated for each consist of orange spotted grouper.

The feeding rate was $3 \%$ of the total biomass of fish per day (Abdullah et al., 2018). The amount of feed was divided into 6 tanks equal portions and distributed by hand in three times daily in morning (8 am), evening (5 pm) and at night (11 pm). Every seven (1 week) days, the fish in each tank were calculated. According to Abdel Hamid (2000) and Ibrahim et al., (2011), the body weight of individual fish was measured to point feed quality and to calculate growth performance. $30 \%$ water changes in every two days interval. The siphoning method was applied. Fish waste at the bottom of the tanks was siphoned out. By using YSI model meter, the water parameter were observed and recorded. The water parameters recorded were temperature, dissolved oxygen, $\mathrm{pH}$ and salinity. The experiment was conducted for 31 days. The body weight of sampled fish will be calculated by using following equations (Mehrim, 2009).

\section{Survival Rate (SR\%)}

$=100 \times$ (end number of the fish alive/ the beginning number of fish)

Mean Weight Gain (g/fish) MWG

$=$ Mean final weight $(\mathrm{g})$ - Mean initial weight $(\mathrm{g})$

\section{Mean Daily Gain}

$=$ Mean weight gain/ experimental period (days)

\section{Specific Growth Rate ( SGR, \%day) =}

$100 \mathrm{x}$ (in final weight - in initial weight/ experimental period $(\mathrm{T}))$

Feed Conversion Rate $($ FCR) $=$ Dry weight of feed consume by fish (g)/ Wet weight.
Feed Effiency Ratio (FCE) = Live Weight Gain (g)/ Dry feed fed (g)

\section{Data analysis}

Data presented as mean \pm standard deviation. Independent sample t-Test was used to determine any significant difference between the experimental group and control groups. The difference between pairs of treatments was considered to be significant if the $\mathrm{P}$-value $<0.05$. All statistical analysis was performed using Microsoft Excel 2010 version 14.0.

\section{Results and Discussion}

\section{Water Quality}

Water quality parameter in all tanks for Treatment and Control tank were within the required range for the growth of Epinephelus coioides during experimental period about 31 days. The water parameter range from temperature $\left(26.4-28.9^{\circ} \mathrm{C}\right)$, dissolved oxygen form 5.8 to $6.4 \mathrm{ppm}, \mathrm{pH}$ from 7.2 to 7.5 , salinity from 29.7 to $31.0 \mathrm{ppt}$, nitrite $(<0.05 \mathrm{ppm})$ and ammonia $(<0.02 \mathrm{ppm})$.

\section{Growth performance}

Growth performance including Mean Weight Gain (MWG), Feed Conversion Ratio (FCR), Specific Growth Rate (SGR), Survival and Weight Gain (WG) of juvenile Epinephelus coioides fed with Treatment Diet (with probiotic Bacillus sp.) and Control Diet (without probiotic) was identified and shown in Table 1. After 31 days of feeding with probiotic and without probiotic no mortality was identified for juvenile Epinephelus coioides.

Table 1 showed the juvenile Epinephelus coioides fed diets with probiotic (Bacillus $\mathrm{sp)}$ in $10^{7}$ concentration has lower weight gain (120.74 \pm 7.04$)$ compared to Control $(193.12 \pm 14.49)$ and show significant difference at $(\mathrm{P}<0.05)$. The result of average daily gain (ADG) showed that Control $(0.07 \pm 0.00)$ was higher compared to Treatment $(0.05 \pm 0.00)$ and show no significant difference at $(\mathrm{P}<0.05)$. Meanwhile, the result for specific growth rate 
(SGR) showed that Control $(0.92 \pm 0.11)$ was higher compared to Treatment $(0.26 \pm 0.08)$ and show significant difference at $(\mathrm{P}<0.05)$. Then, the feed conversion efficiency (FCE) stated that the Control $(0.01 \pm 0.01)$ was lower compared to Experiment $(0.06 \pm 0.01)$ and showed no significant difference at $(\mathrm{P}<0.05)$. For feed conversion ratio (FCR), juvenile that fed with probiotic (Bacillus sp.) showed a higher result at (17.32 \pm 3.59$)$ compared to Control $(13.90 \pm 2.31)$ and has no significant difference at $(\mathrm{P}<0.05)$. The mean weight gain (MGW) showed that Control (2.26 \pm 0.12$)$ was higher compared to Treatment $(1.67 \pm 0.02)$ and has significant difference at $(\mathrm{P}<0.05)$. Lastly, the mean weight gain $(\% \mathrm{WG})$ indicated higher in Control (2.26 \pm 0.12$)$ compared to Treatment $(1.67 \pm 0.02)$ and has significant difference at $(\mathrm{P}<0.05)$.
Meanwhile data in Table 2 shows the result for specific growth rate (SGR) show that Control (1.78 \pm 0.46$)$ was higher compared to Treatment $(1.34 \pm 0.28)$ and showed no significant difference at $(\mathrm{P}<0.05)$. Then, the feed conversion efficiency (FCE) stated that the Control $(0.06 \pm 0.02)$ was higher compared to Treatment $(0.04 \pm 0.01)$ and showed no significant difference at $(\mathrm{P}<0.05)$. For feed conversion ratio (FCR), juvenile that fed with probiotic (Bacillus sp.) showed a higher result at (23.93 \pm 6.59$)$ compared to Control (14.48 2.99$)$ and has significant difference at $(\mathrm{P}<0.05)$. The mean weight gain (MGW) showed that Control $(2.47 \pm 0.34)$ was higher compared to Treatment $(2.37 \pm 0.64)$ and has no significant difference at $(\mathrm{P}<0.05)$.

Table 1 : Growth performance and survival of Epinephelus coioides juvenile fed with probiotic Bacillus sp. in $10^{7}$ concentration (Treatment) and without probiotic (Control) for 14 days

\begin{tabular}{cccccccc}
\hline Tank & MWG(g) & FCR & FCE & SGR(\%) & SURVIVAL & ADG & WG(\%) \\
\hline Control & $2.26^{*}$ & 13.90 & 0.01 & $0.92^{*}$ & 100 & 0.07 & $193.12^{*}$ \\
& \pm 0.12 & \pm 2.31 & \pm 0.01 & \pm 0.11 & \pm 0 & \pm 0.00 & \pm 14.49 \\
\hline $10^{7}$ & $1.67^{*}$ & 17.32 & 0.06 & $0.26 *$ & 100 & 0.05 & $120.74 *$ \\
concentration & \pm 0.02 & \pm 3.59 & \pm 0.01 & \pm 0.08 & \pm 0 & \pm 0.00 & \pm 7.04 \\
\hline
\end{tabular}

Table 2 : Growth performance and survival of Epinephelus coioides juvenile fed with probiotic Bacillus sp. in $10^{6}$ concentration (Treatment) and without probiotic (Control) for 14 days

$\begin{array}{cccccc}\text { Tank } & \text { MWG(g) } & \text { FCR } & \text { FCE } & \text { SGR(\%) } & \text { SURVIVAL } \\ \text { Control } & 2.47 & 14.48^{*} & 0.06 & 1.78 & 100 \\ & \pm 0.34 & \pm 2.99 & \pm 0.02 & \pm 0.46 & \pm 0 \\ 10^{6} & 2.37 & 23.93^{*} & 0.04 & 1.34 & 100 \\ \text { concentration } & \pm 0.64 & \pm 6.59 & \pm 0.01 & \pm 0.28 & \pm 0\end{array}$

Values are mean of replicate groups and presented as mean \pm SE. Control : Fish fed without probiotic. $10^{6}$ and $10^{7}$ concentration : Experiment fish fed with probiotic (Bacillus sp).

Description: $\mathrm{MWG}=$ Mean Weight Gain. $\mathrm{FCR}=$ Feed Conversion Ratio. FCE $=$ Feed Conversion Efficiency. SGR : Specific Growth Rate. $\mathrm{ADG}=$ Average Daily Gain. \%WG : PercentageWeight Gain. *(Has significant difference in $(\mathrm{P}<0.05) . \pm=$ Standard error.

In fish aquaculture, the advantages of using probiotics have particularly attracted farmers' attention. Growth performance improvement is the main beneficial effect of probiotic use in fish aquaculture (Merrifield et al . 2009). Growth performance improvement with probiotics involves nutrient and enzymatic contribution to digestion (Sahu et al., 2008). According to Nayak (2010), the aquaculture industry is among the major consumers of probiotics, Bacillus strains have become increasingly popular and 
widely used in fish aquaculture. Specimen Bacillus sp. can enhance hosts' development as they can produce certain essential nutrients, including amino acids (Sanders et al., 2003) and vitamins $\mathrm{K}$ and $\mathrm{B} 12$. In some probiotics, extracellular enzymes such as proteases and lipases are produced and the necessary growth factors are supplied in the dignifying process. A wide range of Bacillus species can separate nutrients, such as proteins and carbohydrates from a wide variety of exogenzymes. (Liu et al., 2009). In this study, the probiotic (Bacillus sp.) was added to the basal diet of the orange spotted grouper and the effect of this probiotic on the growth performance of juvenile Epinephelus coioides was investigated and recorded.

In this experiment during the 31 days study period, the water parameter that have been recorded were temperature, salinity, dissolved oxygen, $\mathrm{pH}$ value, nitrite and ammonia between ranged of $26.4-28.9^{\circ} \mathrm{C}, 29.8$ - $31.0 \mathrm{ppt}, 5.8$ - 6.4 ppm, $7.2-7.5 \mathrm{pH}$ value, $0.05 \mathrm{ppm}$ and $0.02 \mathrm{ppm}$ respectively. These ranges of values for water parameter are suitable and acceptable for orange spotted grouper culture (Ranjan et al., 2014).

In the first place, the results of the present study indicated that the control had a better result compared to the experiment due to the use of low dosage probiotics. It was suggested that appropriate doses of Bacillus sp. in diet are needed to improve the growth of aquatic animals. Differences in Bacillus strains, animals (species and sizes) and experimental conditions such as the production of probiotic-containing diets and food methods could be attributed. (Zhao et al., 2012). The higher dosage of probiotic used in the experiment will contribute to better growth performance rate. In rainbow trout, Safari et al (2016) stated that the final values for MWG, FCR and SGR between Control and Experiment does not have significant difference but when used higher dosage of probiotic, it will improve the growth performance in experiment significantly. Then Zhao et al (2012) stated that SGR in sea cucumber does not show significant difference when tested with probiotic $10^{5}$ concentration and $10^{7}$ concentration whereas when tested with
$10^{9}$ concentration have significant difference compare to control. Lastly, Chun et al., (2012) also stated that the higher dosage will contribute to higher feed efficiency and percentage weight gain. According to Sun et al., (2010), hepatopancreatic protease activity and feed efficiency increase with usage of probiotics. Higher FCE indicate that a good aquaculture practice whereas as the feed is efficient and could lower the cost of feed consumption.

Survival rate during current study shows survival rate to be at $100 \%$. According to Ahmad et al., (2000), the survival rate of Epinephelus coioides is $\pm 97.5 \%$ depends on loading rate. This is due to the nature of Epinephelus coioides that have high tolerance towards harsh condition and reduce water exchange compare to other species. Then, Bacillus sp. also contribute by enhancing disease resistance in aquatic animals against pathogen through improving the nonspecific immune system (Nayak, 2010).

Because of the growth performance has not significantly improved during the experiment, it can certainly suggest that the inclusion of probiotics (Bacillus sp.) in daily diet for culturing and farming should be increased to achieve better results.

\section{Conclusion}

In conclusion, the use of probiotics (Bacillus sp.) in the rearing of juvenile orange spotted grouper (Epinepehlus coioides) is recommended to improve the growth performance by using higher dosage. The probiotic (Bacillus sp.) plays a major role in enhancing he mean weight gain (MWG), specific growth rate (SGR), average daily gain (ADG) and percentage weight gain (\%WG). Neither $10^{6}$ nor $10^{7}$ concentration of probiotic that were introduced to the daily diets of the juvenile orange spotted grouper showed any significant differences in growth performance. To test whether this probiotic can affect the different species and maintain the positive effect on growth performance, further study is needed. 


\section{Acknowledgements}

Many great people have contributed in the success of finishing my project and my thesis writing and I deeply indebted with them. First of all, I would like to thanks Allah SWT for all His blessing and consent for this study to be completed. Peace and Blessing be upon Prophet Muhammad s.a.w, His family and His company. Thank God for giving me the mental strength, physical strength, matured mind and the free time to complete this study successfully. Appreciation and gratitude for my final year project supervisor, Dr Sharifah Noor Emilia Syed Jamil Fadaak for all her advices, guidance and encouragement throughout the project. Special thanks also dedicated to my final year project teammates, Nur Zahirah, Mohamad Hafizzuddin, Nurfitrah and Muhammad Ikhwan Syafiq who gave their endless support and undivided cooperation to make this project a success and helping me throughout tough time when handling this project. Special thanks also goes to my parents, Mohd Azmi and Anin Zaharah that give me moral support throughout difficult times and finance to enable me completed this project. Thank you also to the staff of Fisheries and Food Sciences for all their help to complete-this project. Thank you to Mr Mat Zain, Mr Adhwa, Mr Khairul and Mr Yaakud form Marine Hatchery for all their effort in taking the time, give advice to solve problems using their experience and help during this project. Thank you also to my batch mate of Aquaculture students that help me in any ways possible during this project. Without the encouragement and support from all of you, it is difficult for me to completed this study. All the sacrifice, tears and sweat will not be forgotten. Thank you once again.

\section{References}

Ababouch, L., Taconet, M., Plummer, J., Garibaldi L. \& Vannuccini, S. (2016). Bridging the sciencepolicy divide to promote fisheries knowledge for all: the case of the Food and Agriculture Organization of the United Nations.

Abalobi. (2017). ABALOBI: a co-designed and fisherdriven mobile app suite to transform small-scale fisheries governance from hook to cook.
Abatenh, E., Gizaw, B., Tsegay, Z. Tefera, G. Aynalem, E. (2018). Health benefits in probiotics.

Afero F, Miao S, \& PerezAA(2009): Economic analysis of tiger grouper Epinephelus fuscoguttatus and humpback grouper Cromileptes altivelis commercial cage culture in Indonesia. Aquac Int 2009. doi:10.1007/s10499- 009-9295-x

Ahmad T.A, El-Dakour S. M \& El-Zahar C. R. (2000). Growth and survival of the grouperEpinephelu scoioides(Hamilton) at different loading rates in the tanks.

Banerjee. G, \& Ray. A. K. (2017). The advancement of probiotics research and its application in fish farming industries. Vol 115, page 66-77.

Blair, J. M.,Webber, M. A., Baylay, A. J., Ogbolu, D. O., \& Piddock, L. J., (2015). Molecular mechanisms of antibiotic resistance, Nat. Rev. Microbiol. 13. 2015. 42-51.

Bongaarts, J. (2009). Human population growth and the demographic transition.

Brown, E. D., \& Wright, G. D., (2016). Antibacterial drug discovery in the resistance area, Nature 569 336-343.

Cabello FC (2006): Heavy use of prophylactic antibiotics in aquaculture: a growing problem for human and animal health and for the environment. Environ Microbiol 2006, 8:1137-1144. Gives an overview of the problematic use of antibiotics in aquaculture and its consequences

Cao. L., Naylor, R., Henriksson, P., et. al., (2015). China's aquaculture and the world's wild fisheries.

Ch'ng, C.L. \& Senoo, S. (2008). Egg and larval development of a new hybrid grouper, tiger grouper Epinephelus fuscoguttatus $\times$ giant grouper E. lanceolatus. Aquaculture Science 56(4): 505-515.

Cook, L. K. N. (1996). Optimizing Culturing Conditions for Bacillus subtilis. South African Avocado Growers' Association Yearbook, 5458.

Deifoirdt,T., Sorgeloos, P., \& Boisser, P., (2011). Alternatives to antibiotics for the control of bacterial disease in aquaculture. 
Dhanaraj, M.,Haniffa, M. A.,Arun Singh, S. V.,Jesu Arockiaraj, A.,Muthu Ramakrishanan, C., Seetharaman, S., \& Arthimanju, R., (2010). Effect of Probiotics on Growth Performance of Koi Carp (Cyprinus carpio), Journal of Applied Aquaculture, 22:3, 202-209, DOI: $10.1080 / 10454438.2010 .497739$.

FAO (2010). The State of World Fisheries and Aquaculture

FAO (2002). The State of World Fisheries and Aquaculture

FAO (2014). The State of World Fisheries and Aquaculture.

Frieden, T. (2013). Antibiotic Resistance Threats in the United States, a report presented to United States Congress by Centers of Disease Control and Prevention (CDC), 2013.

Fuller, R. (1989) .A review : probiotics in man and animals. J. Appl. Bacteriol. 66:365-378.

Glamuzina B, Glavić N, Skaramuca B, Kozul V, \& Tutman P. (2001). Early development of the hybrid $<\mathrm{i}>$ Epinephelus costae $<$ l $\mathrm{i}>q \times<\mathrm{i}>E$. marginatus $</ \mathrm{i}>\hat{O}$. Aquaculture. 2001;198(1):55-61.

Glamuzina B, Tutman P, \& Skaramuca B. (1999) Hybridization of Mediterranean groupers: Epinephelusmarginatus $\bigcirc \times$ E. aeneus $\widehat{\supset}$ and early development. Aquac Res. 1999;30(8):6258.

Hanafi. H. B., Leong. P. C., Merican. Z. O., \& Nagaraj, G., (2013). Aquaculture Development in Malaysia. SEAFDEC/AQD Institutional Repository (SAIR).

Hasan, M, R., \& Halwart, M., (2009). Fish as Feed Input for Aquaculture : Practices, Sustainability and Implications.

Havenaar, R., \& Huis, I., (1992). The lactic acid bacteria in health and disease In: Wood, B.J.B. (Ed). Vol 1, Elsevier, New York, NY, USA.

Heemstra, P.C. (1991) A taxonomic revision of the Eastern Atlantic groupers (Pisces: Serranidae).

Heemstra, P.C. \& Randall, J.E. (1993). FAO Species Catalogue. Groupers of the World (Family: Serannidae, Subfamily: Epinephelinae).
Hussin M. A., Ahmad D. O., Shaharah M. I., Sufian M., \& Teoh P., (2006). Improved Artificial Breeding Techniques of Tiger Grouper (Epinephelus fuscoguttatus)

IUCN. (2014). IUCN Red List of Threatened Species. Version 2014. 1. IUCN 2014. IUCN Red List of Threatened Species.

James C, Al-Thobaiti S, Rasem B, \& Carlos M. (1999) Potential of grouper hybrid (Epinephelus fuscoguttatus $x$ E. polyphekadion) for Aquaculture. Naga. 1999;22(1):19-23.

Kechagia, M., Basoulis, D., Konstantopoulou, S., Dimitriadi, D., Gyftopoulou, K., Skarmoutsou, N., \& Fakiri, E.M., (2013). Health benefits of probiotics: a review. ISRN. Nutr. 2013 (2013), 481651. doi.org/10.5402/2013/481651.

Kiriyakit A, Gallardo W. G., \& Bart A. N., (2011). Successful hybridization of groupers $(<\mathrm{i}>$ Epinephelus coioides $</ \mathrm{i}>\mathrm{x}<\mathrm{i}>$ Epinephelus lanceolatus $</ \mathrm{i}>$ ) using cryopreserved sperm.

Kohno, H., Duray, M. \& Sunyoto, P. (1990). A Field Guide to Groupers of Southeast Asia. Central Research Institute for Fisheries and Japan International Cooperative Agency. Jakarta, Indonesia.

Kohno, H., Imanto, P.T., Diani, S., Slamet, B. \& Sunyoto, P. (1991). Bull. Pen. Perikanan, Special Edition No.1: 27-35pp

Kuo C. M.,. (1995). The Groupers in World Animal Sciences.

Laxminarayan, R., Matsoso, P., Pant, S., Brower, C., Rottingen, J. A., Klugman, K. et al.. (2016). Access to effective antimicrobials : A worldwide challenge.

Liu M., \& Mitcheson Y. S. D., (2008). Grouper aquaculture in Mailand China and Hong Kong.

Liufu H.Z, Liu X.C, Lin H.R, \& Huang G.G. (2007). Preliminary Study on the Hybrid Red-spotted Grouper (Epinephelus akaara) $\hat{\delta} \times$ Orangespotted Grouper (Epinephelus coioides) + . Acta Sci Nat UnivSunyatseni. 2007;46(3):72-5.

Mazlan, A.G., Moumita. D, Simon. K. D., Yosni, B. \& Zaidi, C., C. (2016). Optimum Temperature for the Growth Form of Tiger Grouper (Epinephelus 
fuscoguttatus) x Giant Grouper (Epinephelus lanceolatus) Hybrid Grouper.

McGeoch, M. A., Butchart, S. H. M., Spear, D., Marais, E., Kleynhans, E. J., et al. (2010). Global indicators of biological invasion: species numbers, biodiversity impact and policy responses.

Merrifield, D. L., Bradley, G., Baker, R. T. M., \& Davies, S. J., (2009). Probiotic applications for rainbow trout (Oncorhynchus mykiss Walbaum) II. Effects on growth performance, feed utilization, intestinal microbiota and related health criteria postantibiotic treatment

Meyers, R.A. \& Worm, B., (2003). Rapid worldwide depletion of predatory fish communities. Nature 423: 280283.

Millenn. Ecosyst. Assess. 2005. Millennium Ecosystem Assessment Synthesis Report.

Nayak, S. K., (2010). Probiotics and immunity: a fish perspective. Fish Shellfish Immunol

Noorashikin, M. N., Simon, K. D, Zaidi, C. C., \& Mazlan, A. G. (2018). Effect of salinities and diets on growth of juvenile Hybrid Grouper. Turkish Journal of Fisheries and Aquatic Science 18: 1045-1051. ISSN 1303-2712, DOI: 10.4194/1303-2712-v1894

Othman A.R., Kawamura G., Senoo S., \& Fui C.F. (2015). Effect of different salinities on growth, feeding performance and plasma cortisol level in hybrid TGGG (tiger grouper,Epinephelusfuscog uttatus x giant grouper, Epinepheluslanceolatus) juvenile. International Research Journal of Biological Science 4:15-20.

Ottolenghi F, Silvestri C, Giordano P, Lovatelli A, \& New M.B., (2004). The fattening of eels, groupers, tunas and yellowtails.

Parenti P, \& Bressi N. (2001). First record of the orange-spotted grouperEpinepheluscoioides(Pe rciformes: Serranidae) in the Northern Adriatic Sea.

Pauly, D., Christensen, S. Guénette, T. Pitcher, U.R., Sumaila, C., Walters, R,. Watson,. ... Zeller, D. (2002). Towards sustainability in world fisheries.
Petr P. \& Richardson, D. M., (2010). Invasive Species, Environmental Change and Management, and Health.

Phillips. M, Subasinghe, R, P, et al,. (2016). Aquaculture Big Number.

Pierre. S, Gaillard, S et al,. (2008). Grouper aquaculture : Asian success and Mediterranean trials, Aquatic Conservation Marine and Freshwater Ecosystem.

Pillar,C. \& Sahm, D. (2012). Resistance trends and susceptibility profiles in the US among prevalent clinical pathogens: lessons from surveillance, in: T.J. Dougherty, M.J. Pucci (Eds.), Antibiotic Discovery and Development, 2, Springer, New York, 2012, pp. 753-792.

Pomeroy. R, Agbayani. R, Sugama. K,. et al. (2002). The Status of Grouper culture in Southeast Asia.

Priyadarshini P., Deivasigamani B., Rajasekar T., Edward G. J. G., Kumaran S., Sakthivel M.,\& Balamurugan S. (2013). Probiotic in Aquaculture.

Pysek P, Richardson DM, \& Jarosık V. (2006). Who cites who in the invasion zoo: insights from an analysis of the most highly cited papers in invasion ecology. Preslia 78:437-68

Pysek P, Richardson DM, Rejm'anek M, Webster G, Williamson M, \& Kirschner J. (2004). Alien plants in checklists and floras : towards better communication between taxonomists and ecologists. Taxon53:131- 43 .

Randall, J.E. (1987) A preliminary synopsis of the groupers (Perciformes: Seryanidae: Epinephehnae) of the Indo-Pacific region.

Richardson D.M., Py`sek P, Rejm'anek M, Barbour M.G., Panetta F.D., \& West C.J. (2000). Naturalization and invasion of alien plants: concepts and definitions. Divers. Distrib. 6:93107

Rimmer, M. (1998). Grouper and snapper aquaculture in Taiwan. Austasia Aquaculture 12: 3-7.

Ritesh R, Biji X., Biswajit D., Loveson L., Edward, G. Maheswarudu \& Syda Rao, G., (2014). Domestication and brood stock development of 
the orange spotted grouper, Epinepheluscoioides (Hamilton, 1822) in open sea cage off Visakhapatnam coast.

Rossita S., Faihanna C., Abdullah, Senoo, S., \& Mustafa, S., (2018). Nutrition, growth and resilience of tiger grouper (Epinephelus fuscoguttatus) 3 giant Grouper (Epinephelus lanceolatus) hybrid- a review

Sadovy Y. (2001). Summary of regional survey of fry/fingerling supply for grouper mariculture in southeast Asia.

Safari R., Adel M., Lazado C. C., Caipang C. and Dadar M. (2016) Host-derived probiotics Enterococcus casseliflavus improves resistance against Streptococcus iniae infection in rainbow trout (Oncorhynchus mykiss) via immunomodulation. Fish \& Shellfish Immunology. Volume 52, May 2016, Pages 198-205

Sahu M.K., Swarnakumar N.S., Sivakumar K., Thangaradjou T., \& Kannan L. (2008). Probiotics in aquaculture: Importance and future perspectives. Indian J Microbiol.

Sanders M.E., Morelli L., \& Tompkins T.A. (2003). Sporeformers as human probiotics: Bacillus, Sporolactobacillus, and Brevibacillus. Comp Rev Food Sci Food Saf 2003;2:101e10.

Sen, S., Ingale, S.L., Kim, Y.W., Kim, J.S., Kim, K.H., Lohakare, J.D., Kim, E.K., ... Chae, B.J. (2012). Effect of supplementation of Bacillus subtilis LS1-2 to broiler diets on growth performance, nutrient retention, caecal microbiology and small intestinal morphology. Research in Vet. Sci., 93(1): 264 - 268

Senoo, S. (2006). Hybrid production between tiger grouper Epinephelus fuscoguttatus $\times$ giant grouper Epinephelus lanceolatus(fish culture in Southeast Asia 64). Aquanet Magazine 12: 5863.

Singh, R. B., \& Barrett,J. F., (2006). Empirical antibacterial drugs discovery-Foundation in natural products.
Steenbergen, L., Sellaro, R., van Hemert, S., Bosch, J.A., \& Colzato, L.S., (2015). A randomized controlled trial to test the effect of multispecies probiotics on cognitive reactivity to sad mood. Brain Behav. Immun. 48, 258-264.

Sugama K., Insan I., \& Koesshahrani I., (2008) Hatchery and growth-out technology of groupers in Indonesia.

Sun Y.Z, Yang H.L, Ma R.L, \& Lin W.Y. (2010). Probiotic applications of two dominant gut Bacillus strains with antagonistic activity improved the growth performance and immune responses of grouper Epinepheluscoioides. Fish Shellfish Immunol 2010;29:803e9.

Teng S. K., Chua T. E., \& Lim P. E., (1978). Preliminary observation on the dietary protein requirement of estuary grouper,Epinephelussal moidesMaxwell, cultured in floting net cages.

The State of The World Fisheries And Aquaculture (2016).

Tidwell. J. H, \& Bright. L. A (2018). Freshwater Aquaculture. Reference Module in Earth System and Environmental Sciences.

Tucker J.W. (1999). Species profile grouper aquaculture. Southern Regional Aquaculture Center; SRAC Publication no. 721.

Walsh, C. T., (2003). Antibiotics : Action, Origin, Resistence.

Yan Wang YZ, Haifa Z, Huang W, \& Haoran L. (2014). Comparision of morphology between two kinds of hybrid groupers and their parents. J Fish China. 2014;38(6):778-85.

Zainuddin. (2010). The Effect of Calcium and Phosphorus on Growth, Feed Efficiency, Mineral content and Body Composition of brown marled grouper (E. fuscogutattus) juvenile. J. Sci. Tropic.Mar. 2(2) : 1-9. 
